\title{
The Management of Older Adults with Pancreatic Adenocarcinoma
}

\author{
John R. Ogden ${ }^{1}$ D, Hao Xie ${ }^{2}$, Wen Wee Ma ${ }^{2}$ and Joleen M. Hubbard ${ }^{2, *}$ \\ 1 Division of Internal Medicine, Department of Medicine, Mayo Clinic, Rochester, MN 55905 USA; \\ Ogden.John@mayo.edu \\ 2 Division of Medical Oncology, Department of Oncology, Mayo Clinic, Rochester, MN 55905, USA; \\ Xie.Hao@mayo.edu (H.X.); ma.wen@mayo.edu (W.W.M.) \\ * Correspondence: Hubbard.Joleen@mayo.edu; Tel.: +1-507-266-9160
}

Received: 19 September 2018; Accepted: 23 November 2018; Published: 26 November 2018

\begin{abstract}
Pancreatic cancer is the eleventh most common cancer, yet it is the third leading cause of mortality. It is also largely a disease of older adults, with the median age of 71 at diagnosis in the US, with $<1 \%$ of diagnoses occurring prior to age 50 . Current NCCN guidelines recommend surgery for localized disease, followed by adjuvant therapy and/or consideration of enrollment in a clinical trial. For metastatic disease, current guidelines recommend clinical trial enrollment or systemic chemotherapy based on results from the landmark ACCORD-11 and MPACT trials. However, these trials focused heavily on younger, more fit patients, with the ACCORD-11 trial excluding patients over age 75 and the MPACT trial having $92 \%$ of its patients with a Karnofsky performance score $>80$. This article summarizes the available evidence in current literature in regards to the best treatment options for older adults, who represent the majority of pancreatic cancer diagnoses.
\end{abstract}

Keywords: pancreatic adenocarcinoma; older adults; disease management; localized disease; metastatic disease

\section{Introduction}

Pancreatic cancer has an expected incidence of 55,440 new cases and 44,330 deaths in 2018 in the United States alone [1]. Although it is the eleventh most common cancer, it is the third leading cause of cancer-related death [2]. It is also largely a disease of older adults, with the median age of 70 at diagnosis in the US, with $11 \%$ of diagnoses occurring at age 54 or younger, according to the SEER database [3]. Pancreatic cancer is typically divided into three categories: localized, locally advanced, and metastatic. Currently, localized disease offers the only chance for cure. Unfortunately, only about $10 \%$ of diagnoses are made at the localized stage, largely because symptoms are nonspecific until advanced stage. Because of this, five-year overall survival for pancreatic cancer remains dismally low at $8 \%$ [1].

For localized disease, the 2017 National Comprehensive Cancer Network (NCCN) guideline recommends surgery for patients with good performance status and consideration of enrollment in a clinical trial during their treatment. Adjuvant therapy consisting of chemotherapy and/or concurrent chemo-radiation should be considered following resection [4]. If a patient received neoadjuvant treatment prior to surgical resection, additional adjuvant chemotherapy should still be considered. For metastatic disease, NCCN guideline recommends preferably clinical trial enrollment, FOLFIRINOX therapy, or gemcitabine-based therapy, typically in combination with nab-paclitaxel. The efficacy of FOLFIRINOX regimen was shown to be superior to Gemcitabine alone in the ACCORD-11 trial [5], and the combination of Gemcitabine plus nab-paclitaxel was shown to be superior to Gemcitabine alone in the MPACT trial [6]. However, these trials focused heavily on younger, more fit patients, with 
the ACCORD-11 trial excluding patients over age 75 and the MPACT trial having $92 \%$ of its patients with a Karnofsky performance score $>80$.

This article summarizes the available evidence in current literature in regards to the best treatment options for older adults, who represent the majority of pancreatic cancer diagnoses. We did an extensive search of PubMed using the terms "localized pancreatic cancer", "locally advanced pancreatic cancer", "metastatic pancreatic cancer", "treatment", and "elderly" to find data on what the best treatment options might be for older patients and what discrepancies, if any, exist in the current literature. Table 1 summarizes the articles that were selected for review of the management of localized disease.

\section{Localized Disease}

Localized (or resectable) disease is defined as disease that is confined to the pancreas without extensive invasion of local structures [4]. Specifically, no arterial tumor contact with the celiac, superior mesenteric, or common hepatic arteries, as well as no venous contact with the superior mesenteric vein or $\leq 180$ degree contact with the portal vein without vein contour irregularity. It is optimally treated with surgery, chemotherapy, with/without concurrent chemo-radiation therapy.

\subsection{Who among the Elderly Received Treatment?}

In our review of the literature, we found that elderly patients were significantly less likely to undergo surgical resection compared to their younger counterparts, irrespective of comorbidity status. In a retrospective analysis of the Surveillance, Epidemiology, and End Results (SEER) program database on a total of 2229 patients age 65 and older, the authors found that, in practice, increasing age was an independent variable for foregoing surgical resection. Compared with patients age 65-69, the odds ratio (OR) for receiving surgical resection for patients age 70-74 was 0.84 (95\% CI 0.62-1.14), age 75-79 was $0.74(0.54-1.01)$, age $80-84$ was $0.52(0.37-0.72)$ and age $\geq 85$ was $0.39(0.24-0.62)$. Other factors that favored receiving surgery were male gender, with females having an OR of 0.85 (0.69-1.05); white race, with African Americans having an OR of 0.99 (0.65-1.52); and other races, with an OR of 0.73 (0.52-1.02); however these factors were not statistically significant. Tumor size was also a significant factor in decision for surgery, with tumors $\geq 2 \mathrm{~cm}$ having an OR of 0.33 (0.21-0.52) compared with smaller tumors [7]. In another study by Riall et al., age again was found to be a significant predictor of who received evaluation for surgery and surgery, regardless of comorbidity status, with resection rates of $39 \%$ in those $<70$ years of age, whereas $5 \%$ of patients aged $\geq 85$ underwent resection [8].

\subsection{What Are the Risk/Benefit Considerations for Elderly Patients Undergoing Surgical Resection?}

Previous studies demonstrated that elderly patients who underwent surgery did much better in terms of overall survival compared with patients who did not undergo surgery. A retrospective study by Riall et al. identified 9553 patients age $\geq 65$ from the SEER database diagnosed with locoregional pancreatic adenocarcinoma between 1992 and 2005. Of these, 69\% were evaluated by a surgeon and $25 \%$ underwent surgical resection. Here, surgical resection was shown to have significant improvement in overall survival, with similar survival benefits regardless of age group. Compared to the unresected patients, the HR for survival for patients $<70$ who underwent surgery was $0.46(0.41-0.53)$ compared with unresected patients, a HR of $0.51(0.46-0.58)$ for age 70-74, $0.47(0.41-0.53)$ for age 75-79, 0.43 $(0.37-0.50)$ for age $80-84$, and a HR of $0.35(0.26-0.48)$ for age $\geq 85$. While the survival advantage among resected patients was seen across all age groups, the study did find increased 30 day mortality in older age groups, with in hospital mortality being 7\% in patients aged $65-69$ versus $11.5 \%$ in those aged 85 and older, although not statistically significant $(p=0.41)$ [8].

The results of this retrospective study agreed with other similar studies [7,9-15], including a study by van der Geest et al. of 3845 patients from the Netherlands Cancer Registry who underwent resection for primary pancreatic or periampullary carcinoma. Here, they found that octogenarians had greater 30 day and 90 day postoperative mortality compared to younger patients, with an odds ratio (OR) of 2.26 (1.25-4.06) for 30 day mortality and an OR of 2.48 (1.53-4.02) for 90 day mortality 
compared with patients age $\leq 70$. The survival among octogenarians who underwent surgery were similar to other age groups at one (53\%), three (21\%), and five years (13\%) [9].

\subsection{Which Is a Better Treatment for Localized Disease in the Elderly: Surgery or Chemotherapy?}

Comparing surgery alone versus chemotherapy alone, the previously mentioned study by Marmor et al. evaluated SEER data among 2229 patients $\geq 65$. This study found a significant unadjusted Kaplan Meier mortality benefit of a median OS within the surgery group compared to the chemotherapy only group (15 months versus 10 months $p<0.001)$, however this benefit did attenuate with age (13 months versus 10 months in those age 80 or older $p<0.01$ ) [7].

\subsection{What Is the Role of Adjuvant Chemotherapy?}

The combination of surgery and adjuvant chemotherapy has better outcomes in terms of survival compared with surgery alone. The ESPAC-1 was the first trial to demonstrate a survival advantage with adjuvant chemotherapy in 2004. This phase III, randomized trial analyzed patients who had undergone resection for pancreatic ductal adenocarcinoma and randomized them into 4 separate groups: treatment with chemotherapy alone (fluorouracil), chemoradiotherapy alone (20 Gy over a two-week period plus concurrent fluorouracil), chemoradiotherapy followed by chemotherapy, and observation. When comparing adjuvant chemotherapy with observation, the median survival in patients receiving adjuvant chemotherapy was 20.1 months, compared with 15.5 months in those who did not, with a hazard ratio of 0.71 (95\% CI 0.55-0.92). Additionally, questionnaires regarding quality of life showed no significant differences between those receiving chemotherapy and those who did not [16]. The study included patients age $34-82$, and while $62 \%$ of patients were age $\geq 65$, the overall survival benefits were not stratified by age in this study.

The CONKO-001 trial later demonstrated that adjuvant gemcitabine improved survival following surgery compared with no adjuvant chemotherapy. In this trial, a total of 368 patients were randomized into a treatment group with surgery plus adjuvant gemcitabine, and a control group with surgery alone in an intention to treat analysis. This trial showed that adjuvant treatment with gemcitabine for 6 months following surgery led to statistically significant improvements compared to surgery alone in terms of disease free survival (13.4 months versus 6.7 months), 5-year survival (20.7\% versus $10.4 \%$ ) and overall survival (22.8 months versus 20.2 months). This benefit was not lost with age, as multivariate analysis of age $\geq 65$ showed a hazard ratio of 1.24 (0.99-1.56) [17].

Comparing gemcitabine and 5-FU, the ESPAC-3 trial showed that median overall survival was similar between the two treatment groups, with median survival of 23.6 months and 23.0 months, respectively ( $p=0.39$ ), with median progression free survival of 14.3 months versus 14.1 months. The 5-FU group was noted to have significantly more grade $3 / 4$ stomatitis and diarrhea $(p<0.001)$, whereas the Gemcitabine group was noted to have increased grade $3 / 4$ hematologic toxicity $(p=$ 0.003). Quality-of-life (QOL) domain scores were calculated according to the EORTC QLQ-30 scoring manual, which assesses multiple categories such as pain, fatigue, nausea, and vomiting, emotional and physical functioning as well as cognitive and social functioning. These QOL scores showed no significant difference in overall quality of life between the two groups [18].

Compounding upon the CONKO-001 trial, the ESPAC-4 trial showed the benefits of adjuvant chemotherapy when comparing gemcitabine plus capecitabine versus gemcitabine alone. In the ESPAC-4 trial, 760 patients were divided into the two treatment groups in an intention to treat analysis. The ESPAC-4 trial showed an increase in overall survival of 28 month in the combination arm versus 25.5 months in the Gemcitabine alone control arm. This came at the expense of more grade 3 or 4 toxicities in the combination group, with a total of 608 grade $3-4$ adverse events reported by $63 \%$ of patients in the combination group, compared with 481 grade 3-4 adverse events in 54\% of patients in the monotherapy group. The benefit of combination treatment remained the same regardless of age, with a Forest plot showing a HR of 0.82 in patients age $<65(\mathrm{n}=382)$, and a HR of 0.81 in patients age $\geq 65$ ( $\mathrm{n}=348)[19]$. 
More recently, the PRODIGE-24 trial compared FOLFIRINOX and gemcitabine in the adjuvant setting, given the superiority of FOLFIRINOX that has been demonstrated in the metastatic setting. This phase III, multicenter trial randomly assigned 493 patients into the two treatment groups. With a median follow up time of 30.5 months, the median OS was found to be significantly longer in the FOLFIRINOX group at 54.4 months versus 34.8 months in the gemcitabine arm (HR $=0.59 ; 95 \% \mathrm{CI}$ $0.46-0.76$ ). This trial included patients aged 18-79 with WHO PS $\leq 1$. However, we are awaiting for further analysis that would be necessary to show if this benefit holds true for the older adult patient population [20].

\subsection{Is There Any Role for Radiation Therapy in Localized Disease?}

In the previously mentioned ESPAC-1 trial, when they compared patients who received chemoradiation with those who did not they found that chemoradiation resulted in worse outcomes, with a HR for death of 1.28 (95\% CI 0.99-1.66, $p=0.05$ ) [16]. This data, however, comes from the 2004 ESPAC-1 trial, and therefore may not be applicable to today's practice given the advancements that have occurred in the field of radiation oncology. Highlighting the unintended consequence ESPAC-1 had on radiation therapy, a study conducted by Shinohara et al. analyzed the SEER database from the 5-year time period preceding and following publication of ESPAC-1 to see how it influenced use of postoperative radiation therapy (PORT). There were 1,628 patients in the pre-publication period, compared to 2194 patients in the post-publication period. Their study found that PORT was used significantly less in the post-publication period, with the odds ratio for PORT in the pre-publication period of 1.19 (95\% CI 1.04-1.35) [21].

However, since then there have been some small studies showing benefit to the addition of radiation to chemotherapy. The first randomized study showing this was reported by the Gastrointestinal Tumor Study Group, noting that 22 patients who underwent observation had a median survival of 11 months, compared with a median survival of 20 months in 21 patients who underwent chemoradiation therapy $(p=0.035)$ [22].

Perhaps the most significant trial to assess the role of chemoradiation therapy was the LAP-07 trial, which was a phase III randomized trial comparing the role of chemoradiotherapy versus chemotherapy alone in the postoperative setting. Unfortunately, this trial was conducted primarily in 'younger' and 'fitter' patients and excluded those over the age of 70, and the average patient age was 63. In this study, 449 patients were enrolled and received gemcitabine or gemcitabine plus capecitabine after surgery. They then underwent a second randomization involving patients with progression-free disease after four months. In this second randomization, 136 patients received 2 additional months of the same chemotherapy, and 133 underwent chemoradiotherapy. This study found no significant difference in median overall survival between the two groups, with the chemotherapy group having a median OS of 16.5 months and the chemoradiotherapy group having a median OS of 15.2 months HR 1.03; CI $0.79-1.34)$ [23].

A recent systematic review conducted by Ciabatti et al. analyzed 11 publications that included 1830 patients aged 65 and older looking at the safety of radiation therapy with and without chemotherapy in the treatment of unresectable pancreatic adenocarcinoma. They concluded that radiation therapy in the elderly population was a viable and safe option, with grade $\geq 3(0-52.6 \%$, median $0.5 \%)$ and $\geq 2(0-15 \%$, median $0 \%)$ toxicities similar to that of the general pancreatic adenocarcinoma population, making this a reasonable choice in older adults in whom radiation is being considered [24].

The recently published results of the phase III PREOPANC-1 trial support the use of neoadjuvant chemoradiotherapy in borderline resectable disease. This trial randomized 246 patients with borderline resectable pancreatic cancer to receive either immediate surgery (127 patients) or preoperative chemoradiotherapy (119) in an intention to treat analysis. The early results are quite promising, with the chemoradiotherapy arm having a significantly improved OS compared with immediate surgery (17.1 months versus 13.5 months; HR 0.71; $p=0.047$ ). The study also demonstrates improved 
margin free resection rates $(65 \%$ versus $31 \%, p<0.001)$ in the neoadjuvant group. There was no significant difference in observed grade $\geq 3$ toxicities in either group $(p=0.17)$. While this abstract does show a clear benefit to neoadjuvant chemoradiotherapy in borderline resectable disease, the abstract does not clarify patient age and thus may not be applicable to older adults [25].

While overall there is little to no data or evidence to support or contradict the use of radiation therapy in addition to chemotherapy, advances in radiation therapy could show to provide benefit in the treatment of pancreatic cancer in the proper setting, and larger studies are needed to truly assess its potential role in treatment. 
Table 1. Articles comparing different treatments for localized Pancreatic Cancer.

\begin{tabular}{|c|c|c|c|c|c|c|}
\hline Year/Article & Study Design & $\begin{array}{l}\text { Median Age (Years), } \\
\text { Range }\end{array}$ & Patient Population & Intervention & Outcome $^{1}$ & AEs/Quality of Life \\
\hline 2017 [19] & RCT, phase III & $65(37-81)$ & $\begin{array}{l}\text { Localized disease, } \\
\text { underwent resection, } \\
\mathrm{n}=730\end{array}$ & $\begin{array}{l}\text { Gemcitabine + capecitabine } \\
\text { vs. gemcitabine alone }\end{array}$ & Median OS 28 months vs. 25.5 months & $\begin{array}{l}608 \text { grade } 3-4 \text { toxicities in } \\
\text { combo group, } 481 \text { in control }\end{array}$ \\
\hline 2013 [17] & RCT, phase III & $62(34-82)$ & $\begin{array}{l}\text { Localized disease, } \\
\text { underwent resection, } \\
\qquad \mathrm{n}=368\end{array}$ & Gemcitabine vs. observation & $\begin{array}{l}\text { OS } 22.8 \text { months vs. } 20.2 \text {, disease free } \\
\text { survival } 13.4 \text { months vs. } 6.7\end{array}$ & N/A \\
\hline 2016 [23] & RCT, phase III & $63(57-71)$ & $\begin{array}{l}\text { Locally advanced disease, } \\
\qquad \mathrm{n}=449\end{array}$ & $\begin{array}{c}1 \mathrm{st} \\
\text { Randomization-gemcitabine } \\
\text { or gem + erlotinib 2nd } \\
\text { randomization-same chemo } \\
\text { vs. chemorad. (54 Gy + } \\
\text { capecitabine) }\end{array}$ & $\begin{array}{l}\text { Median OS } 16.5 \text { months for chemo alone } \\
\text { vs. } 15.2 \text { months for chemoradiotherapy }\end{array}$ & Similar $\mathrm{b} / \mathrm{t}$ two groups \\
\hline 2018 [26] & Retrospective & Not given & $\begin{array}{l}\text { Underwent resection, } \mathrm{n}= \\
\quad 727(\mathrm{n} \geq 65=273)\end{array}$ & $\begin{array}{l}\text { Surgical resection young vs. } \\
\text { elderly }\end{array}$ & $\begin{array}{l}\text { Grade IIIB/IV post-op complications } \\
\text { higher in older }(16.8 \% \text { vs. } 9 \%, p=0.002)\end{array}$ & $\begin{array}{l}\text { Overall complication rate } \\
39.6 \% \text { vs. } 33 \% \text { favoring } \\
\text { younger }\end{array}$ \\
\hline 2013 [10] & Retrospective & $65(25-87)$ & $\begin{array}{c}\text { Localized, underwent } \\
\text { resection, } \mathrm{n}=932(<70 \mathrm{n} \\
=580 ; 70-79 \mathrm{n}=288 ;>80 \\
\mathrm{n}=64)\end{array}$ & $\begin{array}{l}\text { Surgical resection young vs. } \\
\text { elderly }\end{array}$ & $\begin{array}{l}\text { HR of } 1.19(0.85-1.66) \text { for age } 70-79 \text { vs. } \\
<70 \text {, HR of } 1.34(0.75-2.38) \text { for age } \geq 80\end{array}$ & Not assessed \\
\hline 2016 [9] & Retrospective & 67 (19-90) & $\begin{array}{l}\text { Localized, underwent } \\
\text { resection } \mathrm{n}=3845\end{array}$ & $\begin{array}{l}\text { Surgical resection young vs. } \\
\text { elderly }\end{array}$ & $\begin{array}{c}\text { Elderly had higher } 30 \text {-day mortality } \\
(4-5-7-8 \% \text { for ages }<70,70-74,75-79 \\
\text { and }>80 \text {, respectively } p<0.001), \text { but } \\
\text { similar } 90-\text { day and } 3 \text {-year survival rates } \\
\text { (6-10-13-12\% 90-day mortality } p<0.001 \\
\text { and 35-33-28-31\% 5-year survival } \\
p<0.001)\end{array}$ & Not assessed \\
\hline 2016 [7] & Retrospective & $\begin{array}{l}\text { All patients age }>65, \\
\text { median age not provided }\end{array}$ & $\begin{array}{c}\text { Potentially resectable } \\
\text { pancreatic AC, } n=2229\end{array}$ & $\begin{array}{l}\text { Surgical resection }+/- \\
\text { chemo vs. chemotherapy } \\
\text { alone }\end{array}$ & $\begin{array}{l}\text { Longer OS for surgery group, attenuated } \\
\text { with increasing age ( } 15 \text { months vs. } 10 \\
\text { months overall, } 13 \text { vs. } 10 \text { in }>80)\end{array}$ & Not assessed \\
\hline 2017 [27] & Retrospective & $\begin{array}{l}\text { All patients age }>66, \\
\text { median age not provided }\end{array}$ & $\begin{array}{l}\text { Localized, underwent } \\
\text { resection, } n=4105\end{array}$ & $\begin{array}{c}\text { Surgical resection alone vs. } \\
\text { surgery w/adjuvant chemo } \\
\text { early }(<12) \text { and late }(>12 \\
\text { months })\end{array}$ & $\begin{array}{l}\text { Early and late chemotherapy had better } \\
6 \text { months and } 1 \text { year survival vs. surgery } \\
\text { alone with better outcomes in the late } \\
\text { chemotherapy group (OR for early = } \\
0.44(0.35-0.53) \text { and } 0.71(0.60-0.85) \text { for } 6 \\
\text { months and } 1 \text { year, respectively, late OR } \\
=0.14(0.10-0.17) \text { and } 0.51(0.43-0.61)\end{array}$ & Not assessed \\
\hline
\end{tabular}


Table 1. Cont.

\begin{tabular}{|c|c|c|c|c|c|c|}
\hline Year/Article & Study Design & $\begin{array}{l}\text { Median Age (Years), } \\
\text { Range }\end{array}$ & Patient Population & Intervention & Outcome $^{1}$ & AEs/Quality of Life \\
\hline $2011[8]$ & Retrospective & $\begin{array}{l}\text { All patients age }>66, \\
\text { median age not provided }\end{array}$ & $\begin{array}{l}\text { Locoregional pancreatic } \\
\text { CA diagnosis, } n=9553\end{array}$ & Surgical resection & $\begin{array}{c}\text { Age independent predictor of resection } \\
\text { regardless of comorbidities compared to } \\
\text { age }<70(70-7421 \% \text { less likely, } 75-79= \\
47 \%, 80-84=72 \%>8594 \%) \text {, benefit of } \\
\text { resection did not decrease with } \\
\text { increasing age }(16.1,15.8,14.9,12.4,12.3 \\
\text { mos. survival } p=0.08)\end{array}$ & Not assessed \\
\hline 2017 [11] & Retrospective & $\begin{array}{l}\text { (38-88) median age not } \\
\text { provided }\end{array}$ & $\begin{array}{l}\text { Underwent resection for } \\
\text { localized PA, } \mathrm{n}=227\end{array}$ & $\begin{array}{l}\text { Resection }+/ \text { - adjuvant } \\
\text { chemo }\end{array}$ & $\begin{array}{c}\text { Median DFS of } 15 \text { months, } 11 \text { months, } \\
\text { and } 7 \text { months for young }(<70) \text {, elderly } \\
\text { ( } 70-80) \text {, and very elderly }(>80) \text {, better for } \\
\text { young }(p=0.012 \text { and } 0.016) \text {, median OS } \\
\text { of } 30 \text { months, } 20 \text { months, and } 14 \text { months } \\
\quad p=0.07 \text { and } p<0.001\end{array}$ & Not assessed \\
\hline 2016 [12] & Retrospective & $\begin{array}{l}\text { (18-90) median age not } \\
\text { provided }\end{array}$ & $\begin{array}{l}\text { Underwent resection for } \\
\text { localized PA, } n=929\end{array}$ & Resection & $\begin{array}{l}\text { Similar } 90 \text { day mortality ( } 3.2 \% \text { vs. } 5 \% \text { in } \\
\text { the younger vs. older, } p=0.09 \text { ) }\end{array}$ & Not assessed \\
\hline 2016 [13] & Retrospective & $68(40-86)$ & $\begin{array}{l}\text { Localized disease, } \\
\text { underwent resection } \mathrm{n}= \\
206\end{array}$ & Resection & $\begin{array}{l}\text { Median OS was similar for young vs. } \\
\text { old ( } 23 \text { and } 17 \text { months, } p=0.40 \text { ), OS at } 1 \text {, } \\
3 \text {, and } 5 \text { years was } 62 \%, 42 \% \text {, and } 25 \% \text { in } \\
\text { young, } 56 \%, 28 \% \text {, and } 28 \% \text { in old }\end{array}$ & $\begin{array}{l}\text { No difference in complication } \\
\text { rate }(26 \% \text { vs. } 20 \% p=0.41)\end{array}$ \\
\hline 2016 [14] & Retrospective & $\begin{array}{c}<75 \text { years } \mathrm{n}=241 \\
(44.9-74.9) \text { median }=66 \geq \\
75 \mathrm{n}=59(75-88) \text { median } \\
=78\end{array}$ & $\begin{array}{l}\text { Underwent resection for } \\
\text { localized PA, } n=300\end{array}$ & Resection & $\begin{array}{l}\text { Similar median OS for age }<75 \text { and } \geq 75 \\
\quad(19.2 \text { vs. } 18.4 \text { months } p=0.175)\end{array}$ & Not assessed \\
\hline 2015 [15] & Retrospective & $\begin{array}{c}<80 \text { years } \mathrm{n}=362(\text { mean } \\
=64.7)>80 \text { yrs } n=23 \\
\quad(\text { mean }=82.6)\end{array}$ & $\begin{array}{l}\text { Underwent resection for } \\
\text { localized PA, } n=385\end{array}$ & Resection & $\begin{array}{l}\text { Similar median OS for age }<80 \text { and }>80 \\
\quad(21 \text { vs. } 19 \text { months } p=0.86)\end{array}$ & Not assessed \\
\hline 2015 [28] & Retrospective & $82(80-88)$ & $\begin{array}{l}\text { Underwent resection for } \\
\text { localized } \mathrm{PA}, \mathrm{n}=26\end{array}$ & $\begin{array}{l}\text { Resection }+/ \text { - adjuvant } \\
\text { chemo }\end{array}$ & $\begin{array}{l}\text { Similar between those who received } \\
\text { chemo vs. did not (1 year survival of } \\
50 \% \text { and } 45 \% \text {, MST of } 12.4 \text { and } 11.7 \\
\text { months } p=0.263 \text { ) }\end{array}$ & Not assessed \\
\hline 2014 [29] & Retrospective & $\begin{array}{c}<80 \text { years } \mathrm{n}=4102 \\
(\text { median }=65) \geq 80 \text { years } \\
\mathrm{n}=475(\text { median }=82)\end{array}$ & $\begin{array}{l}\text { Any age, underwent } \\
\text { resection, } \mathrm{n}=4577\end{array}$ & $\begin{array}{l}\text { Resection }+/ \text { - adjuvant } \\
\text { chemo }\end{array}$ & $\begin{array}{l}\text { Age }>80 \text { had 2-fold increase in } 30 \text { day } \\
\text { mortality than younger (OR }=2.0,95 \% \\
\text { CI 1.3-3.1 } p=0.03) \text { ), similar to age } 70-79 \\
(\text { OR } 1.5,95 \% \text { CI } 0.9-2.4 p=0.120)\end{array}$ & Not assessed \\
\hline
\end{tabular}

${ }^{1}$ OS: Overall Survival; HR: Hazard Ratio; DFS: Disease Free Survival; OR: Odds Ratio; CI: Confidence Interval. 


\section{Metastatic Disease}

\subsection{What Is the Current Standard?}

Metastatic pancreatic adenocarcinoma is not amenable to surgical resection, therefore systemic chemotherapy is the standard of care in attempting to control metastatic disease. The trial by Burris et al. in 1997 was essential in establishing a new standard when it showed that Gemcitabine was superior to 5-FU in advanced disease [30].

Another phase III trial published in 2007 by Moore et al. showed that the addition of Erlotinib to Gemcitabine improved outcomes. This trial randomized 569 patients into the two treatment groups and showed a statistically but not clinically significant effect on survival, with a median OS of 6.24 months versus 5.91 months, and a HR of 0.77 (0.64-0.92). However, subgroup analysis showed this benefit was lost in the 268 patients age $\geq 65$ (47\% of total trial population), with a HR of $0.96(0.74-1.24)$ [31].

In 2011, the ACCORD-11 trial showed superiority of FOLFIRINOX regimen compared with Gemcitabine. In this phase III trial, 342 patients were randomized to the two treatment arms, and FOLFIRINOX was shown to have increased OS compared with Gemcitabine (11.1 months versus 6.8 months). However, the FOLFIRINOX arm had significantly more adverse side effects, including neutropenia, febrile neutropenia, and thrombocytopenia. Additionally, this trial only included patients with an ECOG score of $\leq 1$, and excluded patients over age 75 , with a median age of 61 . The benefit, however, was seen in patients $\geq 65$ with a HR of $0.48(0.30-0.77)$, compared with a HR of $0.61(0.46-0.82)$ in patients $<65$ [5].

In 2013, the MPACT trial showed that the addition of nab-Paclitaxel to Gemcitabine improved outcomes compared to Gemcitabine alone. In this trial, 861 patients were randomized into the two treatment arms, and the combination arm had greater overall survival (8.5 months versus 6.7 months) and better progression-free survival (6.4 months versus 3.3 months). This trial included patients from age $27-88$, with a median age of 63 . However, only patients with a Karnofsky performance status $\geq 70$ were included. A subgroup analysis showed that the benefit on overall survival was not significant in those $\geq 65$, with a HR of $0.81(0.63-1.03)$ compared to a HR of $0.65(0.53-0.79)$ in patients aged $<65$. However, the benefit on progression free survival was maintained in the older population, with a HR of $0.69(0.52-0.91)$ compared with a HR of $0.69(0.55-0.87)$ in those aged <65 [6].

These trials have brought us to our current standards of care for metastatic disease, which consists of FOLFIRINOX or nab-Paclitaxel with Gemcitabine, with less toxic agents used for patients with more comorbidities or poorer performance status. However, these trials focused much more on younger, fitter patients, therefore their generalizability to elderly and those with more comorbidities is unknown. Table 2 summarizes the articles that were selected for review of the management of metastatic disease.

\subsection{How Do Elderly Fare with Treatment for Metastatic Disease Compared with Younger Patients?}

We conducted a literature search to evaluate the data regarding outcomes of older adults receiving treatment for metastatic pancreatic cancer compared with younger patients. A retrospective study done by van der Geest et al. in the Netherlands looked at the Netherlands Cancer Registry and identified 9407 patients who had been diagnosed with metastatic pancreatic cancer between 2005 and 2013. They stratified this population by age and whether or not the patients received treatment, looking specifically at median overall survival. They found that elderly patients in both the treatment and untreated groups had significantly lower median survival times, with a median OS for ages $<70$, $70-74,75-79$, and $>80$ of $26,27,20$, and 16 weeks. Survival times for untreated were $12,11,11$, and 10 weeks respectively according to age group [32]. This study did not stratify treatment groups based on the type of treatment they received, so it is not surprising to see that elderly patients did worse considering they often have more comorbidities and are more likely to receive a reduced dose or less toxic and thereby less efficacious, form of chemotherapy. 


\subsection{How Do They Do with the Current Standard Therapies?}

A study out of the University of Tokyo showed that, with gemcitabine therapy in metastatic disease, comorbidity, but not age, was a prognostic factor in predicting overall survival. This study analyzed 237 patients, 69 of whom were over the age of 75, and found that compared with patients with a Charleston comorbidity index (CCI) of 0 , patients with a CCI of 1 and $\geq 2$ had a hazard ratio for survival of 1.25 (95\% CI 1.03-1.52) and 1.55 (95\% CI 1.05-2.30), respectively. When stratified by CCI, elderly and young patients had similar overall survival advantage [33].

These results seemed to be supported by other, similar studies looking at gemcitabine-based regimens and survival in the elderly. A study by Marechal et al. looked at OS and TTP in 99 patients at their institution. They found no significant difference in OS (240 days versus 220 days) or TTP (119 days vs. 104 days) in those age $<70$ compared with patients over 70 [34].

Studies looking at FOLFIRINOX use in the elderly have yielded similar results. A retrospective study by Baldini et al. looked at 42 patients aged $>70$ who received FOLFIRINOX and found that they had a median OS of 11.6 months with a 12-month survival rate of $52.6 \%$, similar to data from the ACCORD trial. All patients included in this analysis had a performance status ranging from $0-2$. It was noted that toxicities reported in the elderly were actually less than that of the ACCORD trial, with only $23 \%$ reporting grade 3-4 toxicities, mostly neuropathy. However, a higher percentage of the elderly patients in this study required primary dose reductions (66\%) compared with the ACCORD trial, suggesting a readiness to modify dosing according to anticipated toxicities [35].

Another retrospective study looking at FOLFIRINOX use in elderly by Berger et al. looked at 88 patients with metastatic disease who had received FOLFIRINOX and found that OS in patients age $<65$ was 11.2 months compared with those $\geq 65$ where OS was 7.9 months, however this was not found to be a statistically significant difference $(p=0.83)$ [36].

\subsection{What about Less Toxic Regimens, Such as FOLFIRI or FOLFOX?}

A recent meta-analysis by Sonbol et al. demonstrated that FOLFIRI, but not FOLFOX demonstrated a survival advantage over single agent fluoropyrimidine (FP) therapy, as a second line treatment after progression on gemcitabine-based therapy. This analysis included 5 studies included 895 patients with a median age ranging between 61 and 65 for the 5 included manuscripts. The meta-analysis showed that adding irinotecan to FP therapy added an OS benefit $(\mathrm{HR}=0.70 ; 95 \%$ CI 0.55-0.89) when compared to FP therapy alone. However, adding oxaliplatin to FP therapy did not show an OS benefit (HR $=1.03,95 \%$ CI 0.64-1.67) [37].

While this review of studies that included older adults showed a benefit for FOLFIRI as second line therapy, there is limited to no data showing how it might perform as a first line therapy. Additionally, the results of this analysis were not specifically stratified by age groups. However, given the reduced toxicities of FOLFIRI and FOLFOX in comparison with FOLFIRINOX, this may be a reasonable option in older adults with poorer performance status, and more studies are needed to assess this potential therapy. 
Table 2. Articles comparing treatment for metastatic disease.

\begin{tabular}{|c|c|c|c|c|c|c|}
\hline Article/Year & Study Design & Median Age (Range) & Patient Population & Intervention & Outcome $^{1}$ & AEs/Quality of Life \\
\hline $2011[5]$ & $\begin{array}{l}\text { Randomized trial, } \\
\text { phase 3, multicenter, } \\
\text { open-label }\end{array}$ & $61(25-76)$ & $\begin{array}{l}\text { Patients with ECOG } \\
\text { score of } 0 \text { or } 1 \text { with } \\
\text { metastatic pancreatic } \\
\text { CA, } n=342\end{array}$ & $\begin{array}{l}\text { FOLFIRINOX vs. } \\
\text { Gemcitabine }\end{array}$ & $\begin{array}{l}\text { Better OS in FOLFIRINOX ( } 11.1 \text { months } \\
\text { vs. } 6.8 \text { months } p<0.001) \text {, better PFS ( } 6.4 \\
\text { months vs. } 3.3 \text { months } p<0.001)\end{array}$ & $\begin{array}{l}\text { More adverse events in FOLFIRINOX ( } 5.4 \% \text { vs. } \\
1.2 \% \text { had febrile neutropenia, } 9.1 \% \text { vs. } 3.6 \% \\
\text { thrombocytopenia, } 45.7 \text { vs. } 21 \% \text { neutropenia) }\end{array}$ \\
\hline $2013[6]$ & $\begin{array}{l}\text { Randomized trial, } \\
\text { phase 3, multicenter, } \\
\text { open-label }\end{array}$ & $63(27-88)$ & $\begin{array}{l}\text { Advanced pancreatic } \\
\text { CA w/ Karnofsky } \\
\text { performance-status of } \\
70 \text { or more, } \mathrm{n}=861\end{array}$ & $\begin{array}{l}\text { Gemcitabine alone vs. } \\
\text { Gemcitabine }+ \\
\text { nab-paclitaxel }\end{array}$ & $\begin{array}{c}\text { Better OS in combination group ( } 8.5 \\
\text { months vs. } 6.7 \text { months, } p<0.001) \text {, better } \\
\text { PFS ( } 5.5 \text { months vs. } 3.7 \text { months) }\end{array}$ & $\begin{array}{l}\text { More grade } 3 \text { or higher AEs in combination } \\
\text { group-neutropenia ( } 38 \% \text { vs. } 27 \%) \text {, fatigue (17 vs. } \\
7 \% \text { ) and neuropathy ( } 17 \text { vs. } 1 \%)\end{array}$ \\
\hline 2007 [31] & $\begin{array}{l}\text { Randomized trial, } \\
\text { phase 3, multicenter, } \\
\text { open-label }\end{array}$ & $63.9(36.1-92.4)$ & $\begin{array}{c}\text { pts with histologic or } \\
\text { cytologic evidence of } \\
\text { metastatic pancreatic } \\
\text { AC with ECOG of }<2, \\
n=569\end{array}$ & $\begin{array}{l}\text { Gemcitabine }+ \\
\text { Erlotinib vs. } \\
\text { Gemcitabine alone }\end{array}$ & $\begin{array}{l}\text { Better OS in combo group ( } 6.24 \text { months } \\
\text { vs. } 5.91 \text { months }) \text { HR of } 0.82(0.69-0.99) p \\
=0.38 \mathrm{w} / 1 \text {-year survival rates of } 23 \% \\
\text { and } 17 \%(p=0.023) \text {, PFS better in combo } \\
(3.75 \text { months vs. } 3.55 \text { months, HR of } 0.77 \\
\text { (0.64-0.92) } p=0.004)\end{array}$ & $\begin{array}{l}\text { Combination group had higher frequency of } \\
\text { grade I/II A.E.s including rash, diarrhea, } \\
\text { infection, stomatitis, no difference in grade } \\
\text { III/IV }\end{array}$ \\
\hline $1997[30]$ & $\begin{array}{l}\text { Randomized trial, } \\
\text { phase } 3\end{array}$ & $62(36-79)$ & $\begin{array}{c}\text { Advanced } \\
\text { symptomatic } \\
\text { pancreatic cancer, } \mathrm{n}= \\
126\end{array}$ & Gemcitabine vs. 5-FU & $\begin{array}{l}\text { Clinical benefit in } 23.8 \% \text { of } \\
\text { gemcitabine-treated patients vs. } 4.8 \% \text { of } \\
5 \text {-FU ( } p=0.0022) \text {, median OS } 5.65 \\
\text { months vs. } 4.41 \text { months }(p=0.0025) 18 \% \\
\text { vs. } 2 \% 1 \text { year survival }\end{array}$ & No difference in AEs $b / t$ groups \\
\hline 2016 [35] & Retrospective & $73(70-79)$ & $\begin{array}{c}\text { Received } \\
\text { FOLFIRINOX for } \\
\text { advanced pancreatic } \\
\text { AC, } \mathrm{n}=42\end{array}$ & FOLFIRINOX & $\begin{array}{c}\text { Median OS was } 11.6 \text { months }(95 \% \text { CI } \\
\text { 1-74), 12-month survival rate of } 52.6 \% \\
\text { (95\% CI 13.5-85.5), similar to } \\
\text { ACCORD-11 trial }\end{array}$ & 12 patients $(29 \%)$ had grade $3 / 4$ toxicity \\
\hline $2017[36]$ & Retrospective & $56(32-78)$ & $\begin{array}{c}\text { Histology proven } \\
\text { pancreatic AC, } \\
\text { irresectable, ECOG }< \\
1, \text { received } \\
\text { FOLFIRINOX, } \mathrm{n}=88\end{array}$ & FOLFIRINOX & $\begin{array}{l}\text { Median OS was not significantly } \\
\text { different (11.2 months CI 8.9-13.6 for } \\
\text { age <65, 7.9 months CI 5.8-10 for age } \\
\quad>65, p=0.83)\end{array}$ & $\begin{array}{c}\text { No significant difference in grade }>3 \text { tox, } 56.2 \% \\
\text { age }<65,33.3 \% \text { age }>65 \text { ) }\end{array}$ \\
\hline 2016 [38] & Subgroup analysis & $\begin{array}{c}<70 \mathrm{n}=573 ; \geq 70 \mathrm{n}=261 \\
\text { median } / \text { range not } \\
\text { provided }\end{array}$ & $\begin{array}{l}\text { Treated for } \\
\text { unresectable } \\
\text { pancreatic CA, } n= \\
261\end{array}$ & $\begin{array}{l}\text { Gemcitabine + S-1, } \\
\text { S- } 1 \text { alone, or } \\
\text { Gemcitabine alone }\end{array}$ & $\begin{array}{l}\text { No significant diff in OS (10.2 GS, } 8.0 \mathrm{~S}-1 \text {, } \\
8.5 \text { gemc), no difference in objective } \\
\text { response rate }(27.6 \%, 25.3 \%, 14.3 \%)\end{array}$ & $\begin{array}{l}\text { Grade }>3 \text { toxicities more frequent in GS group } \\
\text { than S-1 or gem groups }(p<0.001 \text { and } p=0.016, \\
\text { respectively) }\end{array}$ \\
\hline 2017 [39] & Retrospective & $\begin{array}{c}<65 \mathrm{n}=236 \geq 65 \mathrm{n}=659 \\
\text { median } / \text { range not } \\
\text { provided }\end{array}$ & $\begin{array}{c}\text { Unresectable } \\
\text { pancreatic CA, } \mathrm{n}= \\
895\end{array}$ & $\begin{array}{l}\text { Any chemotherapy } \\
\text { vs. best supportive } \\
\text { care (BCS) }\end{array}$ & $\begin{array}{l}\text { Survival in chemotherapy group was } \\
\text { similar by age ( } 333 \text { days for }<65,274 \\
\text { days for }>65 p=0.09 \text { ) and similar in BSC } \\
(78 \text { days vs. } 84 \text { days, } p=0.83)\end{array}$ & Not assessed \\
\hline 2008 [34] & Retrospective & $\begin{array}{c}<70 \mathrm{n}=57 \geq 70 \mathrm{n}=42 \\
\text { median/range not } \\
\text { provided }\end{array}$ & $\begin{array}{l}\text { Unresectable or } \\
\text { metastatic pancreatic } \\
\text { AC receiving } \\
\text { gemcitabine-based } \\
\text { chemo, } \mathrm{n}=99\end{array}$ & $\begin{array}{l}\text { Gemcitabine-based } \\
\text { chemotherapy }\end{array}$ & $\begin{array}{c}\text { No difference in OS ( } 240 \text { days in }<70 \text { vs. } \\
220 \text { days in }>70, p=0.882 \text { ) or TTP } \\
\text { among elderly vs. young ( } 119 \text { days vs. } \\
104 \text { days, } p=0.846)\end{array}$ & Similar rates between elderly and younger \\
\hline
\end{tabular}


Table 2. Cont

\begin{tabular}{|c|c|c|c|c|c|c|}
\hline Article/Year & Study Design & Median Age (Range) & Patient Population & Intervention & Outcome $^{1}$ & AEs/Quality of Life \\
\hline 2017 [32] & Retrospective & $\begin{array}{c}<70 \mathrm{n}=472970-74 \mathrm{n}= \\
162375-79 \mathrm{n}=1437 \geq 80 \\
\mathrm{n}=1618 \text { median } / \text { range } \\
\text { not provided }\end{array}$ & $\begin{array}{l}\text { Metastatic pancreatic } \\
\text { CA diagnosis in the } \\
\text { NCR, } n=9407\end{array}$ & $\begin{array}{l}\text { Any form of } \\
\text { treatment or no } \\
\text { treatment }\end{array}$ & $\begin{array}{c}\text { Elderly had lower OS in treated ( } 26 \\
\text { weeks, } 27,20,16 \text { for age }<70, \\
70-74,75-79, \text { and }>80 p=0.003) \text { and } \\
\text { untreated }(12,11,11,10 p<0.001) \\
\text { administration of chemo increased b/t } \\
2005-13(26-43 \%, 14-25 \%, 5-13 \% \text { (all } p< \\
0.001) \text {, and } 2-3 \% \text { (not SS) for ages }<70, \\
70-74,75-79 \text {, and }>80 \text { ) }\end{array}$ & Not assessed \\
\hline $2014[40]$ & Retrospective & $73(70-79)$ & $\begin{array}{l}\text { Patients who started } \\
\text { palliative } 1 \text { st line } \\
\text { chemo for advanced } \\
\text { pancreatic CA, } n=53\end{array}$ & $\begin{array}{l}\text { First or second line } \\
\text { palliative systemic } \\
\text { chemotherapy }\end{array}$ & $\begin{array}{c}\text { Elderly have similar OS and PFS rates to } \\
\text { younger from trials (median PFS of } 118 \\
\text { days in }>75 \text {, median OS of } 201 \text { days } \\
(145.5 \text { days for }>75,218 \text { days for }<75, p= \\
0.51)\end{array}$ & $\begin{array}{l}\text { 30.2\% experienced grade }>3 \text { tox, no significant } \\
\text { difference between ECOG } 0-1 \text { vs. }>2 \text { ) }\end{array}$ \\
\hline $2011[41]$ & Retrospective & $75-84(78)$ & $\begin{array}{c}\text { Patients } \mathrm{w} / \text { advanced } \\
\text { or metastatic } \\
\text { pancreatic AC, } \mathrm{n}=38\end{array}$ & $\begin{array}{l}\text { Single agent } \\
\text { gemcitabine } \\
\text { according to the } \\
\text { Burris regimen or } \\
\text { GemOx regimen }\end{array}$ & $\begin{array}{c}\text { Median OS was } 8.9 \text { months, similar to } \\
\text { younger }\end{array}$ & $\begin{array}{l}23 \% \text { experienced grade } 3 \text { toxicity (neutropenia), } \\
\text { no grade } 4 \text {, similar to younger }\end{array}$ \\
\hline 2010 [33] & Retrospective & $\begin{array}{c}67.8+/-10.7(\text { Mean }+/- \\
\text { SD) }<75 \mathrm{n}=168 \geq 75 \mathrm{n}= \\
69\end{array}$ & $\begin{array}{c}\text { Patients diagnosed } \\
\text { with unresectable } \\
\text { pancreatic } C A, n= \\
237\end{array}$ & $\begin{array}{l}\text { Any treatment } \\
\text { modality }\end{array}$ & $\begin{array}{l}\text { Compared with CCI score of } 0, \text { CCI of } 1 \\
\text { and }>2 \text { had a HR of } 1.25 \text { and } 1.55, \\
\text { respectively. Age not a poor prognostic } \\
\text { factor (OS between non elderly and } \\
\text { elderly who received chemo was } 10.8 \\
\text { and } 10.9 \text { months, respectively) }\end{array}$ & No difference in elderly vs. younger \\
\hline
\end{tabular}

${ }^{1}$ OS: Overall Survival; HR: Hazard Ratio; DFS: Disease Free Survival; OR: Odds Ratio; CI: Confidence Interval; CCI: Charleston Comorbidity Index 


\section{Conclusions}

Our literature review finds that healthy and fit older patients should be offered the standards for 'younger and fit' patients though the survival benefit of surgery, radiation and chemotherapy may be diminished with advancing age. As always, a careful assessment of risks and benefits for each treatment modality need to be reviewed with the patient. This is especially true for surgical intervention, where the post-operative mortality increased with age $(>70)$ and more than doubled in octogenarians who underwent surgical resection.

Older patients had also been excluded from large randomized trials including ACCORD11 that excluded age $>75$ metastatic patients, and LAP-07 that excluded age $>70$ patients with locally advanced disease; therefore, limiting their generalizability to older patients. Interestingly, a subgroup analysis of the MPACT trial showed that the survival advantage of more intensive chemotherapy in metastatic patients age $>65$ was not statistically significant suggesting the need to examine the potential benefit of intensive chemotherapy in the older age groups. In addition, the standards-changing pivotal randomized trials had focused on 'good performing' patients and provided little to guide the treatment of those who are considered 'treatable' but with 'borderline' performance status.

We advocate that more systematic studies should be conducted to evaluate the risk-benefit considerations of contemporary pancreatic cancer therapy in older patients, particularly those older than 75 . The available evidence suggests that patients who are not candidates for aggressive therapy may still achieve a survival benefit with less toxic regimens such as single agent gemcitabine, FOLFOX, or FOLFIRI. Ideally, future studies will include a geriatric assessment to determine the fitness of the patient, which will help guide the patient and clinician to make the most appropriate choice among the various treatment regimens for the individual older patient with pancreatic cancer.

Funding: This research received no external funding.

Conflicts of Interest: The authors declare no conflict of interest.

\section{References}

1. Siegel, R.L.; Miller, K.D.; Jemal, A. Cancer statistics, 2018. CA Cancer J. Clin. 2018, 68, 7-30. [CrossRef] [PubMed]

2. Cancer Facts \& Figures 2018. Available online: https://www.cancer.org/content/dam/cancer-org/research/ cancer-facts-and-statistics/annual-cancer-facts-and-figures / 2018/cancer-facts-and-figures-2018.pdf (accessed on 23 October 2018).

3. Zhang, Q.; Zeng, L.; Chen, Y.; Lian, G.; Qian, C.; Chen, S.; Li, J.; Huang, K. Pancreatic Cancer Epidemiology, Detection, and Management. Gastroenterol. Res. Pract. 2016, 2016, 8962321. [CrossRef] [PubMed]

4. Tempero, M.A.; Al-Hawary, M.; Bain, A.; Malafa, M.; Asbun, H.; Behrman, S.; Benson, A.; Binder, E.; Cardin, D.; Cha, C.; et al. NCCN Guidelines Index Table of Contents Discussion NCCN Guidelines Version 3.2017 Panel Members Pancreatic Adenocarcinoma Cassadie Moravek ¥ Pancreatic Cancer Action Network NCCN Guidelines Panel Disclosures. 2017. Available online: https:/ /www.tri-kobe.org/nccn/guideline/ pancreas/english/pancreatic.pdf (accessed on 25 June 2018).

5. Conroy, T.; Desseigne, F.; Ychou, M.; Bouché, O.; Guimbaud, R.; Bécouarn, Y.; Adenis, A.; Raoul, J.L.; Gourgou-Bourgade, S.; de la Fouchardière, C.; et al. FOLFIRINOX versus Gemcitabine for Metastatic Pancreatic Cancer. N. Engl. J. Med. 2011, 364, 1817-1825. [CrossRef] [PubMed]

6. Von Hoff, D.D.; Ervin, T.; Arena, F.P.; Chiorean, E.G.; Infante, J.; Moore, M.; Seay, T.; Tjulandin, S.A.; Ma, W.W.; Saleh, M.N.; et al. Increased Survival in Pancreatic Cancer with nab-Paclitaxel plus Gemcitabine. N. Engl. J. Med. 2013, 369, 1691-1703. [CrossRef] [PubMed]

7. Marmor, S.; Burke, E.E.; Virnig, B.A.; Jensen, E.H.; Tuttle, T.M. A comparative analysis of survival outcomes between pancreatectomy and chemotherapy for elderly patients with adenocarcinoma of the pancreas. Cancer 2016, 122, 3378-3385. [CrossRef] [PubMed]

8. $\quad$ Riall, T.S.; Sheffield, K.M.; Kuo, Y.-F.; Townsend, C.M.; Goodwin, J.S. Resection Benefits Older Adults with Locoregional Pancreatic Cancer Despite Greater Short-Term Morbidity and Mortality. J. Am. Geriatr. Soc. 2011, 59, 647-654. [CrossRef] [PubMed] 
9. Van der Geest, L.G.M.; Besselink, M.G.H.; van Gestel, Y.R.B.M.; Busch, O.R.; de Hingh, I.H.; de Jong, K.P.; Molenaar, I.Q.; Lemmens, V.E. Pancreatic cancer surgery in elderly patients: Balancing between short-term harm and long-term benefit. A population-based study in the Netherlands. Acta Oncol. (Madr.) 2016, 55, 278-285. [CrossRef] [PubMed]

10. Turrini, O.; Paye, F.; Bachellier, P.; Sauvanet, A.; Sa Cunha, A.; Le Treut, Y.P.; Adham, M.; Mabrut, J.Y.; Chiche, L.; Delpero, J.R.; et al. Pancreatectomy for adenocarcinoma in elderly patients: Postoperative outcomes and long term results: A study of the French Surgical Association. Eur. J. Surg. Oncol. 2013, 39, 171-178. [CrossRef] [PubMed]

11. Sugiura, T.; Okamura, Y.; Ito, T.; Yamamoto, Y.; Ashida, R.; Uesaka, K. Impact of Patient Age on the Postoperative Survival in Pancreatic Head Cancer. Ann. Surg. Oncol. 2017, 24, 3220-3228. [CrossRef] [PubMed]

12. Brahmbhatt, B.; Bhurwal, A.; Lukens, F.J.; Buchanan, M.A.; Stauffer, J.A.; Asbun, H.J. Pancreatic Surgery in the Older Population: A Single Institution's Experience over Two Decades. Curr. Gerontol. Geriatr. Res. 2016, 2016, 8052175. [CrossRef] [PubMed]

13. Miyazaki, Y.; Kokudo, T.; Amikura, K.; Kageyama, Y.; Takahashi, A.; Ohkohchi, N.; Sakamoto, H. Age does not affect complications and overall survival rate after pancreaticoduodenectomy: Single-center experience and systematic review of literature. Biosci. Trends 2016, 10, 300-306. [CrossRef] [PubMed]

14. Renz, B.W.; Khalil, P.N.; Mikhailov, M.; Graf, S.; Schiergens, T.S.; Niess, H.; Boeck, S.; Heinemann, V.; Hartwig, W.; Werner, J.; et al. Pancreaticoduodenectomy for adenocarcinoma of the pancreatic head is justified in elderly patients: A Retrospective Cohort Study. Int. J. Surg. 2016, 28, 118-125. [CrossRef] [PubMed]

15. Beltrame, V.; Gruppo, M.; Pastorelli, D.; Pedrazzoli, S.; Merigliano, S.; Sperti, C. Outcome of pancreaticoduodenectomy in octogenarians: Single institution's experience and review of the literature. J. Visc. Surg. 2015, 152, 279-284. [CrossRef] [PubMed]

16. Neoptolemos, J.P.; Stocken, D.D.; Friess, H.; Bassi, C.; Dunn, J.A.; Hickey, H.; Beger, H.; Fernandez-Cruz, L.; Dervenis, C.; Lacaine, F.; et al. A Randomized Trial of Chemoradiotherapy and Chemotherapy after Resection of Pancreatic Cancer. N. Engl. J. Med. 2004, 350, 1200-1210. [CrossRef] [PubMed]

17. Oettle, H.; Neuhaus, P.; Hochhaus, A.; Hartmann, J.T.; Gellert, K.; Ridwelski, K.; Niedergethmann, M.; Zülke, C.; Fahlke, J.; Arning, M.B.; et al. Adjuvant Chemotherapy With Gemcitabine and Long-term Outcomes Among Patients With Resected Pancreatic Cancer. JAMA 2013, 310, 1473-1481. [CrossRef] [PubMed]

18. Neoptolemos, J.P.; Stocken, D.D.; Bassi, C.; Ghaneh, P.; Cunningham, D.; Goldstein, D.; Padbury, R.; Moore, M.J.; Gallinger, S.; Mariette, C.; et al. Adjuvant Chemotherapy With Fluorouracil Plus Folinic Acid vs. Gemcitabine Following Pancreatic Cancer Resection. JAMA 2010, 304, 1073-1081. [CrossRef] [PubMed]

19. Neoptolemos, J.P.; Palmer, D.H.; Ghaneh, P.; Psarelli, E.E.; Valle, J.W.; Halloran, C.M.; Faluyi, O.; O'Reilly, D.A.; Cunningham, D.; Wadsley, J.; et al. Comparison of adjuvant gemcitabine and capecitabine with gemcitabine monotherapy in patients with resected pancreatic cancer (ESPAC-4): A multicentre, open-label, randomised, phase 3 trial. Lancet 2017, 389, 1011-1024. [CrossRef]

20. Conroy, T.; Hammel, P.; Hebbar, M.; Ben Abdelghani, M.; Wei, A.C.C.; Raoul, J.L.; Chone, L.; Francois, E.; Artru, P.; Biagi, J.J.; et al. Unicancer GI PRODIGE 24/CCTG PA.6 trial: A multicenter international randomized phase III trial of adjuvant mFOLFIRINOX versus gemcitabine (gem) in patients with resected pancreatic ductal adenocarcinomas. J. Clin. Oncol. 2018, 36. [CrossRef]

21. Shinohara, E.T.; Mitra, N.; Fei, W.; Kirschner, A.N.; Metz, J.M. Trends in the Use of Postoperative Radiation Therapy in Patients With Localized Resectable Pancreatic Cancer. Am. J. Clin. Oncol. 2012, 35, 543-548. [CrossRef] [PubMed]

22. Hoffe, S.; Rao, N.; Shridhar, R. Neoadjuvant vs. Adjuvant Therapy for Resectable Pancreatic Cancer: The Evolving Role of Radiation. Semin. Radiat. Oncol. 2014, 24, 113-125. [CrossRef] [PubMed]

23. Hammel, P.; Huguet, F.; van Laethem, J.L.; Goldstein, D.; Glimelius, B.; Artru, P.; Borbath, I.; Bouché, O.; Shannon, J.; André, T.; et al. Effect of Chemoradiotherapy vs. Chemotherapy on Survival in Patients With Locally Advanced Pancreatic Cancer Controlled After 4 Months of Gemcitabine With or Without Erlotinib. JAMA 2016, 315, 1844-1853. [CrossRef] [PubMed] 
24. Ciabatti, S.; Cammelli, S.; Frakulli, R.; Arcelli, A.; Macchia, G.; Deodato, F.; Cilla, S.; Giaccherini, L.; Buwenge, M.; Morganti, A.G. Radiotherapy of pancreatic cancer in older patients: A systematic review. J. Geriatr. Oncol. 2018. [CrossRef] [PubMed]

25. Van Tienhoven, G.; Versteijne, E.; Suker, M.; Groothuis, K.B.; Busch, O.R.; Bonsing, B.A.; de Hingh, I.H.; Festen, S.; Patijn, G.A.; de Vos-Geelen, J.; et al. Preoperative chemoradiotherapy versus immediate surgery for resectable and borderline resectable pancreatic cancer (PREOPANC-1): A randomized, controlled, multicenter phase III trial. J. Clin. Oncol. 2018, 36. [CrossRef]

26. Chen, Y.-T.; Ma, F.-H.; Wang, C.-F.; Zhao, D.-B.; Zhang, Y.-W.; Tian, Y.-T. Elderly patients had more severe postoperative complications after pancreatic resection: A retrospective analysis of 727 patients. World J. Gastroenterol. 2018, 24, 844-851. [CrossRef] [PubMed]

27. Nayar, P.; Chandak, A.; Gupta, N.; Yu, F.; Qiu, F.; Ganti, A.K.; Are, C. Postoperative mortality following multi-modality therapy for pancreatic cancer: Analysis of the SEER-Medicare data. J. Surg. Oncol. 2017, 115, 158-163. [CrossRef] [PubMed]

28. Kinoshita, S.; Sho, M.; Yanagimoto, H.; Satoi, S.; Akahori, T.; Nagai, M.; Nishiwada, S.; Yamamoto, T.; Hirooka, S.; Yamaki, S.; et al. Potential role of surgical resection for pancreatic cancer in the very elderly. Pancreatology 2015, 15, 240-246. [CrossRef] [PubMed]

29. Lee, D.Y.; Schwartz, J.A.; Wexelman, B.; Kirchoff, D.; Yang, K.C.; Attiyeh, F. Outcomes of pancreaticoduodenectomy for pancreatic malignancy in octogenarians: An American College of Surgeons National Surgical Quality Improvement Program analysis. Am. J. Surg. 2014, 207, 540-548. [CrossRef] [PubMed]

30. Burris, H.A., 3rd; Moore, M.J.; Andersen, J.; Green, M.R.; Rothenberg, M.L.; Modiano, M.R.; Cripps, M.C.; Portenoy, R.K.; Storniolo, A.M.; Tarassoff, P.; et al. Improvements in Survival and Clinical Benefit With Gemcitabine as First-Line Therapy for Patients With Advanced Pancreas Cancer: A Randomized Trial. J. Clin. Oncol. 1997, 15, 2403-2413. [CrossRef] [PubMed]

31. Moore, M.J.; Goldstein, D.; Hamm, J.; Figer, A.; Hecht, J.R.; Gallinger, S.; Au, H.J.; Murawa, P.; Walde, D.; Wolff, R.A.; et al. Erlotinib Plus Gemcitabine Compared with Gemcitabine Alone in Patients With Advanced Pancreatic Cancer: A Phase III Trial of the National Cancer Institute of Canada Clinical Trials Group. J. Clin. Oncol. 2006, 25, 1960-1966. [CrossRef] [PubMed]

32. Van der Geest, L.G.M.; Haj Mohammad, N.; Besselink, M.G.H.; Lemmens, V.E.P.P.; Portielje, J.E.A.; van Laarhoven, H.W.M.; Wilmink, J.H.W.; Dutch Pancreatic Cancer Group. Nationwide trends in chemotherapy use and survival of elderly patients with metastatic pancreatic cancer. Cancer Med. 2017, 6, 2840-2849. [CrossRef] [PubMed]

33. Nakai, Y.; Isayama, H.; Sasaki, T.; Sasahira, N.; Tsujino, T.; Kogure, H.; Yagioka, H.; Yashima, Y.; Togawa, O.; Arizumi, T.; et al. Comorbidity, not age, is prognostic in patients with advanced pancreatic cancer receiving gemcitabine-based chemotherapy. Crit. Rev. Oncol. Hematol. 2010, 78, 252-259. [CrossRef] [PubMed]

34. Maréchal, R.; Demols, A.; Gay, F.; de Maertelaer, V.; Arvanitaki, M.; Hendlisz, A.; Van Laethem, J.L. Tolerance and Efficacy of Gemcitabine and Gemcitabine-Based Regimens in Elderly Patients With Advanced Pancreatic Cancer. Pancreas 2008, 36, e16-e21. [CrossRef] [PubMed]

35. Baldini, C.; Escande, A.; Bouché, O.; El Hajbi, F.; Volet, J.; Bourgeois, V.; Renaut Vantroys, T.; Ploquin, A.; Desauw, C.; Hebbar, M. Safety and efficacy of FOLFIRINOX in elderly patients with metastatic or locally advanced pancreatic adenocarcinoma: A retrospective analysis. Pancreatology 2017, 17, 146-149. [CrossRef] [PubMed]

36. Berger, A.K.; Haag, G.M.; Ehmann, M.; Byl, A.; Jäger, D.; Springfeld, C. Palliative chemotherapy for pancreatic adenocarcinoma: A retrospective cohort analysis of efficacy and toxicity of the FOLFIRINOX regimen focusing on the older patient. BMC Gastroenterol. 2017, 17, 143. [CrossRef] [PubMed]

37. Sonbol, M.B.; Firwana, B.; Wang, Z.; Almader-Douglas, D.; Borad, M.J.; Makhoul, I.; Ramanathan, R.K.; Ahn, D.H.; Bekaii-Saab, T. Second-line treatment in patients with pancreatic ductal adenocarcinoma: A meta-analysis. Cancer 2017, 123, 4680-4686. [CrossRef] [PubMed]

38. Imaoka, H.; Kou, T.; Tanaka, M.; Egawa, S.; Mizuno, N.; Hijioka, S.; Hara, K.; Yazumi, S.; Shimizu, Y.; Yamao, K. Clinical outcome of elderly patients with unresectable pancreatic cancer treated with gemcitabine plus S-1, S-1 alone, or gemcitabine alone: Subgroup analysis of a randomised phase III trial, GEST study. Eur. J. Cancer 2016, 54, 96-103. [CrossRef] [PubMed] 
39. Kuroda, T.; Kumagi, T.; Yokota, T.; Azemoto, N.; Hasebe, A.; Seike, H.; Nishiyama, M.; Inada, N.; Shibata, N.; Miyata, H.; et al. Efficacy of chemotherapy in elderly patients with unresectable pancreatic cancer: A multicenter review of 895 patients. BMC Gastroenterol. 2017, 17, 66. [CrossRef] [PubMed]

40. Berger, A.K.; Abel, U.; Komander, C.; Harig, S.; Jäger, D.; Springfeld, C. Chemotherapy for advanced pancreatic adenocarcinoma in elderly patients (70 years of age): A retrospective cohort study at the National Center for Tumor Diseases Heidelberg. Pancreatology 2014, 14, 211-215. [CrossRef] [PubMed]

41. Hentic, O.; Dreyer, C.; Rebours, V.; Zappa, M.; Lévy, P.; Raymond, E.; Ruszniewski, P.; Hammel, P. Gemcitabine in elderly patients with advanced pancreatic cancer. World J. Gastroenterol. 2011, 17, 3497-3502. [CrossRef] [PubMed]

(C) 2018 by the authors. Licensee MDPI, Basel, Switzerland. This article is an open access article distributed under the terms and conditions of the Creative Commons Attribution (CC BY) license (http:/ / creativecommons.org/licenses/by/4.0/). 